\title{
CORRESPONDENCE
}

\section{Late Precambrian glacial climate and the Earth's obliquity - a discussion}

SIR - Dr Williams (1975) presents an impressive list of objections to a glacial origin for Late Precambrian mixtites, and then attempts to remove them by postulating a greatly increased obliquity of the ecliptic in Late Precambrian time. If his theory proves inadequate, the objections remain.

\section{Glaciation at low palaeolatitudes}

The main attraction of the theory for ice age adherents must be that it provides an explanation for the common occurrence of Late Precambrian supposed glacigene rocks at low palaeolatitudes. However, as Dr Williams indicates, world climatic zoning would still be related to latitude. The effects of each equatorial glaciation at sea level would girdle the earth, forming an unambiguous and readily recognizable marker horizon till, aquatill or glaciomarinite depending on the depositional environment - wherever equatorial strata of that age remain. In fact, the 'very wide extent of late Precambrian glaciation' is a misconception. Though mixtite formations of that age are widespread, they are markedly discontinuous.

Unlike the Pleistocene tills, with their international correlation, the Late Precambrian mixitites were deposited in detached areas and are not correlatable even over small distances (compare, for example, fig. 3 in Schermerhorn, 1974a). No Late Precambrian mixtite formation comes even close to covering the vast area occupied by the Pleistocene or Permo-Carboniferous icecaps. Moreover, in the seas adjacent to these icecaps a narrow aquatill fringe formed, passing to a wide zone of ice-rafted glaciomarinites. Such is unknown from the Late Precambrian.

\section{Varves}

Dr Williams attaches great importance to the common association of Late Precambrian mixtites with laminated fine-grained sediments, which he considers to be varves indicating a strongly seasonal climate. We feel it is naive to interpret all or even most of such laminites as varves. Marine glacial varves of Pleistocene or Recent date are unknown. True glacial varves are deposited as seasonal ccuplets in small sheltered bodies of fresh water, and are preserved because there are no scouring bottom currents. In the extensive shallow areas, which Dr Williams believes $(1975$, p. 446) to have been typical of the Late Precambrian mixtite environment, reworking of sediment would have been the rule, and seasonal varves would not have been preserved.

The West Congo mixtites, with which we are familiar, are associated with thick, monotonously uniform, clay/silt laminite formations of geosynclinal extent (M1, Se1, and levels in C2 and M0; Schermerhorn \& Stanton, 1963a). Although, in the strange world postulated by Dr Williams, the least-disturbed weather might be expected in low latitudes (Mr J. D. Hanwell, pers. comm.), it is unreasonable to suppose that a sea as big as the Caspian was permanently so serene that the laminites (characterized by graded bedding) could be shallow-water deposits. On the contrary, shallow-water strata, equally of geosynclinal extent, are easily distinguished by all the usual criteria where they occur in the West Congo basin.

We concluded, and we see no reason to change our view, that the laminites were Geol. Mag. 114 (1), 1977, pp. 57-64. Printed in Great Britain. 
deposited in deep water by pulsatory turbidity currents and that they have no seasonal significance.

\section{Dolomites and mixtites}

The close association, in Late Precambrian mixtite sequences, of these supposedly hot and cold palaeoclimatic indicators is an embarrassment to ice-age adherents that Dr Williams' theory does little to relieve. The need for frequent, major, rapid changes in world climate is not removed. The interesting and by no means unique Garvellachs occurrence mixtite with sandstone wedges overlain by dolomite (Spencer, 1971, p. 34) - still requires the transition from glacial through permafrost to warm marine conditions to have taken place over 10000 years or more, with less than 20 m erosion of the imperfectly consolidated mixtite. This is in spite of the violent weather regimes that must have accompanied such a climatic change, and the fact that the coastline with its powerful erosive potential must have transgressed across the mixtite.

It is remarkable that, although on the ice-age theory many fluctuations between glacial subaerial and warm submarine environments must have taken place during the accumulation of the Port Askaig 'tillite', the formational sequence as a whole is hardly more complex than the English marine Jurassic (Spencer, 1971, plates 9-11).

One of us has argued (Schermerhorn, 1974a, $b, 1976)$ that mixtites of proved glacial origin, whether Precambrian or later, are never associated with dolomites or other warm-water facies. A mixtite is not in itself a palaeoclimatic indicator, and when dolomites and mixtites occur together the assemblage is unquestionably a warm-water one unless other cold-water indicators of equal weight are present.

\section{Non-glacial origin for dropstones}

If, as Dr Williams asserts, dropstones indeed occur in laminated dolomites, there can be no reasonable doubt that one of the palaeoclimatic indicators is unreliable; either the dolomites are not warm-water precipitates, or the dropstones were emplaced by an agent other than floating ice.

If the composition of, for example, the West Congo mixtites were truly representative of glacier load, i.e. till, and if those hypothetical glaciers during ice retreat or advance became icebergs that dropped their load into accumulating silt/clay laminites, sand-sized erratics should outnumber pebble-sized ones by something like 100 to 1 . Such, at least, is the case for undoubted ice-rafted sediments of Permo-Carboniferous, Pleistocene and Recent age. We were unable to find any dropstone strata in the West Congo, but it seems to be typical of most such strata associated with Late Precambrian sand-bearing mixtites that the erratics are largely of pebble grade.

This curious selectivity suggests that more serious attention should be paid to the possibility of dropstone emplacement by other means than the classic ones of ice bergs or floes. For example, the bottom-anchored seaweeds cast up on the beach after a storm are usually fixed to a stone or a shell, with at best a few grains of sand caught up in the anchor growth. Spencer (1971, p. 34) dismisses 'rafting by Pre-Cambrian seaweeds' for dropstone beds in the Port Askaig Formation, but his figure 16 illustrating dropstone diameters shows precisely the selectivity (lack of sand-sized clasts) referred to. Before dropstones are acceptable as indicative of ice-age conditions it must be shown that the bulk compositicn of the erratic material is appropriate to floating ice in local glacial circumstances.

Although stones fall through water with their flat sides normal to the direction of fall (Conybeare \& Crook, 1968), coming to rest flat upon the sea bed, dropstones lying at a sharp angle to the bedding not infrequently occur. Kröner (in Schermerhorn, 1974b) mentions 'countless examples' of dropstones whose edges penetrate underlying laminae due to the force of their fall, which fact disproves, he states, Conybeare \& Crook's experimental findings. Having checked the matter ourselves, we maintain that pebbles falling freely through water will hit the bottom gently, in the flat position.

A more likely explanation for angled dropstones, on the seaweed hypothesis, is that their rest position was determined by the remains of the attached weed, which sub- 
sequently decayed. There appears to be no sound reason to reject the possibility that marine algae with rafting potential existed in the Late Precambrian, nor that in particular circumstances they could raft large numbers of stones.

\section{Variety of the published evidence}

When Dr Williams asserts that 'few geologists now query a glacial origin for the [Late Precambrian] mixtites', he seems to support this statement by not quoting those authors who, as a result of their field research, did query a glacial origin. He only quotes early reconnaissance work in mixtite regions where modern comprehensive studies inferred non-glacial deposition (e.g. Blackwelder, 1932, but not Condie, 1967 for North Utah mixtites); such selectivity must detract from the force of his argument.

Particularly disheartening is Dr Williams's choice of 'unequivocal evidence' in the case of the Angolan tilloids, on which we and our colleagues worked for many years in a regional geological survey. We find that these tilloids are listed as wholly glacigene, associated with glaciofluvial deposits, iron formation, varved argillite and dolomite, and glacial dropstones within varved argillite. Because we have described these formations in a regional synthesis (Schermerhorn \& Stanton, 1963a) and several map memoirs (see below), in petrographical, sedimentological and stratigraphical detail not often paralleled for other Late Precambrian mixtite formations, we are able to reject this list. Dr Williams' source is an article based on a brief excursion made under unfavourable conditions (Kröner \& Correia, 1973), subsequently refuted (Schermerhorn, $1974 b$ ). Kröner \& Correia presented as proof of glacial origin a 'glacial dropstone' which we recognize as a siltstone intraclast in banded argillaceous siltstones. It is irrelevant to the tilloid problem because it belongs to a formation underlying the lowest tilloid and separated from it by a major stratigraphic gap. One might equally claim that because fish teeth are found in the Carboniferous Limestone, the Coal Measures are marine.

Kröner \& Correia presented no new data on the Angolan tilloids beyond the alleged discovery of striated stones in $\mathrm{C} 0$, which is open to doubt. Their remaining 'evidence' appeared to consist of their interpretation of stratigraphical and lithological information selected from Schermerhorn \& Stanton (1963a). Kröner (in Schermerhorn, 1974b) argued that a siltstone 'dropstone' $8 \mathrm{~mm}$ wide by $2 \mathrm{~mm}$ thick can weigh $11.4 \mathrm{~g}$, and that only one publication had appeared on the Angolan tilloids before Kröner \& Correia (1973). We suppose that Dr Williams's reliance on Kröner \& Correia (1973) as the authoritative work on Angolan tilloids, in preference to Schermerhorn \& Stanton $(1963 a, b)$, Stanton, Korpershoek \& Schermerhorn (1962), Korpershoek (1964) and Stanton (1972), all of which works contain detailed original information on the tilloids and their setting, may reflect his confidence that the mudflow theory of mixtite formation is a minority viewpoint (p. 447), best ignored.

\section{Climate at increased obliquity of the ecliptic}

At a $90^{\circ}$ tilt of the Earth's axis, the polar region at summer solstice would support a deep persistent thermal depression, with incessant thunderstorms of unparalleled intensity. Land areas would experience prolonged disastrous flooding, tidal surges, and violent winds. As the equinox approached, activity would decrease. In the dark postequinoctial cooling period (which might not be long enough to allow freezing of heated oceanic areas) there would be an initial intense precipitation of atmospheric moisture. Then, polar and middle latitudes would become a vast anticyclonic province with cold outflowing air inhibiting precipitation except locally where warm seas bordered cold lands. Glaciers could not develop, and the following post-equinoctial spring would see early melting of the snow, with violent flooding.

Low latitudes would, in contrast, be relatively serene regions, the noonday sun moving from zenith to horizon and back twice in the year, with a distinct day/night cycle. Middle latitudes would experience transitional climates between the polar and equatorial limits. The development of ice-caps and glaciers would only be possible in a narrow equatorial belt owing to the intense summer insolation at higher latitudes. 
The distribution of water masses would introduce major unpredictable variables into this simplistic scheme, and climate in equatorial regions would be profoundly affected by the pattern of ocean currents.

\section{Conclusions}

Dr Williams's theory accounts for the apparent preference of Late Precambrian 'glacials' for low palaeolatitudes, but it solves none of the other problems faced by ice-age enthusiasts. It does not explain the intimate association of warm dolomites and 'cold' mixtites, nor the local impersistent nature of Late Precambrian mixtites. Neither lateritic weathering nor the formation of evaporites could be expected under such climatic regimes. For warm-water conditions to pertain all the year round at low latitudes (permitting thick dolomite accumulation) polar summer temperatures would have to reach almost unimaginable heights. Evidence of the intensely high-energy polar and middle-latitude environments is lacking. Climate in low latitudes would indeed be strongly seasonal (two summers and winters each year), but we are unconvinced by Dr Williams's geological evidence for this.

We conclude that Dr Williams's theory is inadequate, and that the paradoxes that follow on the belief that Late Precambrian mixtites are glacigene stand undiminished. It is unnecessary, because the mixtites are readily explicable as non-glacial sediments.

\section{References}

Blackwelder, E. 1932. An ancient glacial formation in Utah. J. Geol. 40, 289-304.

Condie, K. C. 1967. Petrology of the Late Precambrian Tillite (?) Association in Northern Utah. Bull. Geol. Soc. Am. 78, 1317-44.

Conybeare, C. E. B. \& Crook, K. A. W. 1968. Manual of Sedimentary Structures. Bureau of Mineral Resources, Geology and Geophysics, Bull. 102. Canberra.

Korpershoek, H. R. 1964. The geology of Degree Sheet Sul B-33/H-N (Noqui-Tomboco). Bol. Serv. Geol. \& Minas Angola 9, 5-183; 10, 5-105.

Kroner, A. \& Correia, H. 1973. Further evidence for glaciogenic origin of late Precambrian mixtites in Angola. Nature Phys. Sci., Lond. 246, 115-117.

Schermerhorn, L. J. G. 1974(a). Late Precambrian mixtites: glacial and/or nonglacial? Am. J. Sci. 274, 673-824.

Schermerhorn, L. J. G. 1974(b). No evidence for glacial origin of late Precambrian tilloids in Angola. Nature, Lond. 252, 114-116.

Schermerhorn, L. J. G. 1976. Late Precambrian mixtites: glacial and/or nonglacial: reply to discussions. Am. J. Sci. 276, 375-84.

Schermerhorn, L. J. G. \& Stanton, W.I.1963(a). Tilloids in the West Congo geosyncline. Q. Jl geol. Soc. Lond. 119, 201-41.

Schermerhorn, L. J. G. \& Stanton, W. I. 1963(b). The geology of Degree Sheet Sul B-33/U (Bembe). Bol. Serv. Geol. \& Minas Angola 7, 5-101.

Spencer, A. M. 1971. Late Pre-Cambrian glaciation in Scotland. Mem. geol. Soc. Lond. $6,100 \mathrm{pp}$.

Stanton, W. I. 1972. Folha Sul B-33/V Carmona-Sanza Pombo, Noticia Explicativa. Serv. Geol. Minas Angola, 34 pp.

Stanton, W. I., Korpershoek, H. R. \& Schermerhorn, L. J. G. 1962. The geology of Degree Sheet Sul B-33/I-O (Săo Salvador). Bol. Serv. Geol. \& Minas Angola 6, 15-86.

Williams, G. E. 1975. Late Precambrian glacial climate and the Earth's obliquity. Geol. Mag. 112, 441-65.

\author{
W. I. STANTON \\ Kites Croft \\ Westbury sub Mendip \\ Wells \\ Somerset
}

\author{
L. J. G. SCHERMERHORN \\ Geological Institute \\ State University of Utrecht \\ Oude Gracht 320 \\ Utrecht \\ The Netherlands
}

18th January 1976 
SIR - Drs Stanton and Schermerhorn's comments centre around their well-known objection to the now widely accepted proposal of important glaciation during the late Precambrian. Indeed, Dr Schermerhorn appears to oppose proposals of glaciation virtually on principle, also having attacked the concept of Late Ordovician glaciation in NW Africa (Schermerhorn, 1971), despite impressive evidence in its favour. Their polemic concerning late Precambrian glaciation has been pursued and answered at length elsewhere (Schermerhorn, 1974a; Young, 1976; Williams, 1976), but their present critique contains additional assertions requiring reply.

They state that late Precambrian mixtite formations are 'markedly discontinuous'. On the contrary, mixtitic horizons may characterize late Precambrian successions over regions of continental extent. In Australia, for example, two such horizons, each bearing substantial evidence of glacial deposition, are present in Proterozoic basins together spanning a distance of about $3000 \mathrm{~km}$; the lower horizon in particular may prove to be an important marker (Dunn, Thomson \& Rankama, 1971). International correlation of such Precambrian facies cannot, of course, be expected to match the precision applied to their Pleistocene counterparts.

Their comments on my references to varves in late Precambrian sequences will come as a surprise to anyone who has carefully read the paper and noted that I was at pains to make clear the subjectivity of this term (see Williams, 1975, pp. 441, 445-6, 449-50, 454, 459 ), to the extent of including it in quotes in table 2 . The numerous geologists whom I cited as recognizing varves or varve-like laminae in late Precambrian glaciogenic sequences will hardly be flattered at the implication that they are naïve. Regarding the contiguity of mixtites and certain 'varvites', Stanton and Schermerhorn underestimate the rise in sea level that would accompany glacial retreat. Thus, mixtite deposition in shallow water might reasonably be followed by tranquil deposition in deeper offshore basins in which laminites could accumulate well below wave base. The abundance of laminites interpretable as marine glacial varvites in certain late Precambrian successions is but one of numerous differences between the deposits of late Precambrian and Pleistocene glaciations which the hypothesis of increased obliquity during late Precambrian time attempts to explain.

I make no apology for taking a stance on the glacial origin of numerous late Precambrian mixtites which are closely associated with dolomites and other indicators of a warm palaeoclimate. This enigma is recognized by numerous competent geologists and is not satisfactorily resolved by refuting a glacial origin for all the mixtites. As I have pointed out (Williams, 1975 , p. $457 ; 1976$ ), the weak-to-moderate climatic zonation that would prevail with increased obliquity $\left(>54^{\circ}\right)$ might well allow the superimposition of cold and warm palaeoclimatic indicators with Milankovitch-type oscillations of global climate. Today, by contrast, the relatively small obliquity $\left(\sim 23.5^{\circ}\right)$ results in a strong climatic zonation, causing a wide latitudinal separation of regions of ice-cap and warmwater sedimentation and hence the mutual exclusion of respective facies from the same sedimentary sequences.

Stanton and Schermerhorn should reflect that glacial dropstones indicate melting ice and hence an absence of frigidity at the place and time of their deposition. It is thus possible that with conditions of considerably weakened climatic zonation resulting from an increased obliquity, glacial dropstones might occur locally within warmwater facies. That Dr Schermerhorn's interpretation of dropstones in Angola is debatable is demonstrated by Kröner \& Correia (1973) and Kröner (in Schermerhorn, 1974b).

The claim that I omitted unfavourable evidence is unjustified. On page 447 I cited Dr Schermerhorn's major work (Schermerhorn, 1974a), which presents his interpretation of late Precambrian mixtitic sequences throughout the world, with the express purpose of enabling interested readers to study a conflicting, albeit minority, viewpoint. The latest published work I cited on Utah rocks was Crittenden et al. (1971), which hardly can be classed as 'early reconnaissance work'. Dr Crittenden subsequently has carried out further field studies in Utah and has identified glacial dropstones and other glaciomarine features in these rocks (written comm., 1974).

I proposed that an obliquity $>54^{\circ}$ could explain the seemingly enigmatic features of 
the late Precambrian climate. Stanton and Schermerhorn select the extreme value of $90^{\circ}$ and paint an imaginative scene in which important features are:

(1) Glaciation confined to low latitudes.

(2) The global climate strongly seasonal.

(3) Seasonally high rainfall and very warm temperatures over wide areas. Such conditions would stimulate weathering and the formation of iron-rich regoliths.

(4) Seas seasonally warmed. Such seas would be favourable sites for the seasonal deposition of dolomites and other warm-water facies.

They do not discuss the global climate for an obliquity near $54^{\circ}$, nor do they mention the geologically important feature of weakened climatic zonation with an increased obliquity. Nonetheless, it is heartening that Dr Schermerhorn has discarded his earlier view of the global climate for a large obliquity (Schermerhorn, 1976).

In conclusion, Drs Stanton and Schermerhorn agree that the model of increased obliquity $\left(>54^{\circ}\right)$ can explain low-to-middle-latitude glaciation and strong seasonality, proposed features of the late Precambrian climate that find considerable support in the literature. Due to the weak-to-moderate climatic zonation that would prevail for an obliquity $>54^{\circ}$, the model might explain also the puzzling superimposition of glaciogenic and warm-water facies. As I concluded (Williams, 1975, p. 459), the hypothesis of increased obliquity must be subjected to rigorous multidisciplinary tests; it is to be hoped this discussion will encourage the carrying out of such tests.

It is opportune to correct here several typographic errors in my paper. Page 456, fifth line from top, for 'altitudes' read 'latitudes'. Page 457, sixteenth line from bottom, should read '.. low-latitude zone (say $\left.\lesssim 30^{\circ}\right) \ldots$ '

\section{References additional to those above}

Crittenden, M. D., Schaeffer, F. E., Trimble, D. E. \& Woodward, L. A. 1971. Nomenclature and correlation of some upper Precambrian and basal Cambrian sequences in western Utah and southeastern Idaho. Bull. geol. Soc. Am. 82, 581-602.

Dunn, P. R., Thomson, B. P. \& Rankama, K. 1971. Late Pre-Cambrian glaciation in Australia as a stratigraphic boundary. Nature, Lond. 231, 498-502.

Schermerhorn, L. J. G. 1971. Upper Ordovician glaciation in northwest Africa? Discussion. Bull. geol. Soc. Am. 82, 265-8.

Williams, G. E. 1976. Late Precambrian mixtites: glacial and/or nonglacial? Discussion. Am. J. Sci. 276, 370-4.

Young, G. M. 1976. Late Precambrian mixtites: glacial and/or nonglacial? Discussion. Am. J. Sci. 276, 366-70.

BHP Melbourne Research Laboratories $\quad$ G. E. WILLIAMS

P.O. Box 264

Clayton, Victoria 3168

Australia

12th February, 1976 